Review

\title{
Potential for Development of an Escherichia coli-Based Biosensor for Assessing Bioavailable Methionine: A Review
}

\author{
Vesela I. Chalova ${ }^{1,2, \dagger}$, Clifford A. Froelich, Jr. ${ }^{1, \ddagger}$ and Steven C. Ricke ${ }^{1,2, *}$
}

1 Poultry Science Department, Texas A\&M University, College Station, TX 77843-2472, USA; E-Mails: veselachalova@gmail.com (V.I.C.); CFroel@1suhsc.edu (C.A.F.)

2 Center for Food Safety and Department of Food Science, University of Arkansas, Fayetteville, AR 72704, USA

$\dagger$ Current address: Department of Biochemistry and Molecular Biology, University of Food Technologies, Plovdiv, Bulgaria.

¥ Current address: Department of Biochemistry and Molecular Biology, Louisiana State University Health Science Center, Shreveport, LA 71129, USA.

* Author to whom correspondence should be addressed; E-Mail: sricke@uark.edu; Tel.: +1-(479) 575-4678; Fax: +1-(479) 575-6936.

Received: 8 February 2010; in revised form: 11 March 2010 / Accepted: 26 March 2010 / Published: 8 April 2010

\begin{abstract}
Methionine is an essential amino acid for animals and is typically considered one of the first limiting amino acids in animal feed formulations. Methionine deficiency or excess in animal diets can lead to sub-optimal animal performance and increased environmental pollution, which necessitates its accurate quantification and proper dosage in animal rations. Animal bioassays are the current industry standard to quantify methionine bioavailability. However, animal-based assays are not only time consuming, but expensive and are becoming more scrutinized by governmental regulations. In addition, a variety of artifacts can hinder the variability and time efficacy of these assays. Microbiological assays, which are based on a microbial response to external supplementation of a particular nutrient such as methionine, appear to be attractive potential alternatives to the already established standards. They are rapid and inexpensive in vitro assays which are characterized with relatively accurate and consistent estimation of digestible methionine in feeds and feed ingredients. The current review discusses the potential to develop Escherichia coli-based microbial biosensors for methionine bioavailability quantification. Methionine biosynthesis and regulation pathways are overviewed in relation to genetic manipulation required for the
\end{abstract}


generation of a respective methionine auxotroph that could be practical for a routine bioassay. A prospective utilization of Escherichia coli methionine biosensor would allow for inexpensive and rapid methionine quantification and ultimately enable timely assessment of nutritional profiles of feedstuffs.

Keywords: methionine; microbial biosensors; Escherichia coli; bioavailability

\section{Introduction}

Methionine is an essential amino acid for animals and is involved in numerous metabolic processes [1-4]. In addition to being a building block in protein synthesis, methionine, after being transformed into S-adenosylmethionine, serves as a methyl donor in transmethylation reactions involved in the biosynthesis of lipids, biotin, and polyamines [5]. Since methionine cannot be synthesized de novo in mammal cells, its supplementation in animal diets is required to provide optimal growth and physiological performance of the animals. Plant proteins, however, are poor in methionine and its optimal level in animal diets is provided by supplementation with crystalline methionine [6] or methionine analogs such as 2-keto-4-(methylthio) butyric acid [7] and hydroxymethionine [8,9]. Therefore, timely and accurate pre-quantification of this amino acid in feed ingredients is necessary to improve cost efficiency of feed formulation and prevent its overdosage. According to Klasing and Austic [10] and Baker [11], excess of individual amino acids due to feed mixing errors can be potentially harmful to the animal, with methionine considered to be the amino acid possessing the highest toxicity. Feed compounds such as cysteine, vitamin $\mathrm{B}_{12}$, arginine, choline, and sulfate that are related to methionine metabolism can affect the apparent methionine requirement of animals and additionally complicate the estimation of the optimal dosage of this amino acid in animal diets [12].

Chemical assays including high performance liquid chromatography (HPLC) are commonly used to quantify methionine level in feed ingredients. The analysis, however, involves pretreatment of the samples with performic acid followed by acid digestion $[13,14]$. The procedure results in a complete protein degradation and liberation of methionine which differs from protein digestion under physiological conditions. Feed-derived methionine, which is available to animals to assimilate, can be more accurately estimated by animal or microbial assays which are considered to correspond more directly to the physiological needs of animals $[15,16]$. Although considered standard, animal assays are laborious, expensive, and time consuming [17-19]. The types of animal assays that have been used for quantifying methionine availability have been reviewed extensively by Froelich and Ricke [18] and will not be discussed further in the current review. Microbial assays appear to be easier and more affordable for routine analysis. Rapid development and recent improvements in molecular techniques allow for constructing successful and accurate amino acid biosensors via more precise genetic targeting of specific genes in microbial cells. This review discusses methionine biosynthesis and regulation in Escherichia coli and the potential of genetically modifying this microorganism into practical whole cell biosensors for methionine bioavailability quantification. 


\section{Microbial Biosensors}

Recently, numerous microbial biosensors have been created and used in medical diagnostics, food technology, biotechnology, and environmental monitoring. Microbial biosensors couple a biological element (enzymes, viable or non-viable microbial cells) and a transducer or a device which allows for rapid, accurate and sensitive detection of target analytes [20,21]. Their popularity is due to highly specific selectivity to the substrate of interest, relative inexpensiveness, and portability [22,23]. Versatile microorganisms have proven to be useful in development of biosensors. The bacterium Vibrio harveyi and Mycena citricolor, a fungal microorganism, demonstrated high sensitivity for detecting cyanide and sodium monofluoroacetate respectively [24]. A microbial biosensor for sensitive, selective, rapid, and direct determination of $p$-nitrophenyl (PNP) -substituted organophosphates was developed based on PNP oxidation metabolic pathway of the Moraxella sp. [25]. Flavobacterium sp. were employed for development of a biosensor for methyl parathion pesticide [26]. The variety and versatility among microbial species useful in the construction of biosensors for environmental application is more extensively discussed elsewhere [20,27] and will not be further discussed here.

In the food industry, microbial biosensors, derived from Gluconobacter oxydans and yeast have gained popularity for detecting total sugars, sucrose, and ethanol [28,29]. Respiratory activities of Gluconobacter oxydans DSM 2343 cells, immobilized on chitosan, were used in the quantification of glucose. A linear relationship $\left(\mathrm{R}^{2}=0.99\right)$ between sensor's response and substrate concentration was achieved in the range of 0.05 to $0.1 \mathrm{mM}$ glucose [23]. By using a microbial biosensor based on immobilized Saccharomyces ellipsoideus yeast cells, Rotariu et al. [29] were able to determine ethanol concentrations up to $50 \mathrm{mM}$ in alcoholic beverages including two types of beer, vodka, and cognac. The comparison to the chemical assay used for the analyses of the same analyte revealed good correlation (correlation coefficient 0.998) between the biosensor and the spectrometric method. An Acetobacter pasteurianus-based biosensor has been proposed as an alternative to chemical methods available for quantifying lactate which is used as an indicator for specific fermentations activities including those of milk, yogurt, and wine [30,31]. Aeromonas phenologenes-, Pseudomonas fluorescens-, and Bacillus subtilis-based biosensors were proposed to serve as alternatives in quantification of amino acids including tyrosine, tryptophan, and glutamate $[32,33]$.

\section{E. coli as a Biosensor}

Among all microorganisms, E. coli is one of the most highly investigated bacteria for the purposes of biosensor fabrication. It is easy to cultivate, with simple nutritive requirements and rapid growth [34]. E. coli is a Gram negative microorganism with very well known genetics which enables the construction of a wide variety of biosensors [20,21]. The complete E. coli genome has been sequenced and the information deposited to the National Center for Biotechnology Information (NCBI) [35]. Thus, each DNA sequence of interest is routinely available to the public and can be used for a wide range of potential further genetic manipulations. In promoter-based E. coli biosensors, a gene promoter, inducible by the analyte of interest, is fused to a reporter that generates a signal in response to the analyte that can be easily monitored and measured. A strong SOS E. coli promoter fused to a lux gene resulted in the development of a construct which served in a dose-dependent 
detection of 6 genotoxic chemicals including mitomycin $\mathrm{C}, \mathrm{N}$-methyl- $N$-nitro- $N$-nitrosoguanidine, nalidixic acid, dimethylsulfate, hydrogen peroxide, and formaldehyde [36]. An E. coli BL21 DE3 (RIL) biosensor strain displayed a specific response and high sensitivity to different aromatic aldehydes. The response was measured by monitoring the fluorescence of a reporter (green fluorescent protein) fused to an alcohol dehydrogenase inducible promoter (Sso2536adh) belonging to the archaeon Sulfolobus solfataricus [37]. A plasmid-borne transcriptional fusion between the E. coli nitrate reductase (narG) promoter and the Photorhabdus luminescens lux operon was used to generate a modified $E$. coli with a highly bioluminescent phenotype in the presence of nitrate that enabled the detection of nitrate to a level of $5 \times 10^{-5} \mathrm{~mol} \mathrm{~L}^{-1}(0.3 \mathrm{ppm})$ [38]. Following the same approach, biosensors for toluene, arsenite and arsenate, and lead have also been generated [39-41].

In addition to environmental testing and analyses, $E$. coli-based biosensors were found to be useful in the food industry as well. E. coli derived $\beta$-galactosidase, glucose oxidase, and horseradish peroxidase were immobilized on a glassy carbon electrode to generate a biosensor for quantification of lactose in raw milk [42]. Simultaneous determination of various mono- and disaccharides was performed by a sensor array comprised of bacterial mutants of E. coli K12 lacking different transport systems for individual carbohydrates [43].

\section{E. coli as a Biosensor for Amino Acid Bioavailability}

Amino acids are building monomers in protein synthesis and indicators for protein quality which explains the interest in constructing microbial biosensors for their quantification. Successful whole-cell biosensors for the quantification of threonine, tryptophan, lysine and glutamine have been developed based on E. coli auxotrophy for the respective amino acids [44-46]. Wild type E. coli can synthesize all amino acids and does not require their supplementation in media. However, auxotrophic mutants that are defective in the biosynthesis of the amino acid of interest grow in a dose-dependent fashion in response to the external concentration of the amino acid. In addition, E. coli is a part of the intestinal microflora of most animals and humans with high similarity in the assimilation of amino acids and peptides which is a necessary prerequisite for the bacterium to serve as a representative biosensor microorganism for these compounds [47]. After pre-treating feed ingredients with pronase and peptidase, Erickson et al. [48] obtained a correlation of 0.94 between lysine bioavailability determined by using an $E$. coli lysine auxotroph and previously published chick bioassay data. Indeed, in a direct experimental comparison, the E. coli biosensor developed by Chalova et al. [19] proved to be as accurate as a chick bioassay for quantitation of bioavailable lysine in diverse feed ingredients and mixtures including soybean meal, cotton seed meal, meat and bone meal, chick starter and finisher, and swine starter.

Early efforts for microbial quantification of methionine have also been based on bacterial auxotrophy. Hitchens et al. [45] demonstrated that E. coli GUC41 could grow on DL-methionine sulfoxide but not on DL-methionine sulfone. The microbiological assay was as accurate as the chemical assay with high correlation coefficients between the two. The microbiological assay values for amino acid content were expressed as percentages of the HPLC values to obtain the bioavailability values. By using E. coli ATCC 23798, a methionine auxotroph, Zabala-Díaz et al. [49] were able to quantify crystalline methionine added to feed. The feed matrix had negligible influence on the assay and methionine recovery percentages for all supplementation levels ranged from 71 to $80 \%$ indicating 
consistency in the bacterial response to the supplemented methionine. The E. coli methionine growth assay has also been miniaturized and adapted to be conducted in microtiter plates where a linear response of the E. coli auxotroph to up to $26.8 \mu \mathrm{M}$ methionine was achieved [50].

In general, this early assay work with $E$. coli methionine auxotrophs supports the feasibility of this approach and potential reliability for routine use. However, there are also limitations with these particular E. coli methionine auxotrophs. To the best of our knowledge, E. coli methionine auxotrophs used for methionine quantification so far have been generated via chemical mutation [51-53]. This mutation method is a "hit-or-miss" approach that mutates the organism in random locations, followed by a selection of a certain phenotype. As a result, the mutation is not target specific and various non-methionine related genes can be affected. Revertants or compensatory mutations may occur to abolish the desired functionality [54]. In addition, in the case of methionine, the auxotrophic requirements for this amino acid are not specific and can also be satisfied by a variety of compounds including methioninyl peptides, $\alpha$-hydroxy methionine, $N$-acetylmethionine, and the $\alpha$-keto analogue $\alpha$-keto- $\lambda$-methiol butyrate [55]. When a chemically generated E. coli methionine auxotroph (ATCC 23798) was used, Froelich et al. [56] established no differences based on substrate affinities of an $E$. coli methionine auxotroph to methionine and methionine hydroxy analog, respectively. Estimated maximum growth rate of the $E$. coli auxotroph when grown on both substrates was also found to be similar.

Although the E. coli methionine auxotroph did not discriminate between methionine and its hydroxyl analog, it appears that both sources are not equally assimilated by animals. While studying the efficacy of both methionine and methionine hydroxyl analog supplementation of pig diets, Shoveller et al. [57] established that methionine hydroxyl analog is significantly less bioavailable compared to DL-methionine for protein deposition in growing pigs. Similar observations were made by Feng et al. [58] who reported the methionine hydroxyl analog to be $26.8 \%$ and $54.4 \%$ less effective than methionine for growing pigs with respect to nitrogen retention and plasma urea nitrogen respectively. Therefore, more specific mutagenesis that targets specific gene(s) without altering other metabolic pathways would be a more desirable approach to generate a microbial biosensor for discriminating and quantifying specific forms of methionine. Detailed knowledge about E. coli's genomics and more specifically, the genes involved in methionine biosynthesis and transportation is a prerequisite to accomplish such a goal and is the focus of the discussion in the following sections.

\section{Biosynthesis of Methionine in E. coli}

Methionine's carbon skeleton is initially derived from aspartate. The intermediates of this pathway, aspartyl semialdehyde and homoserine, are also used in the synthesis of lysine and threonine. Serine and cysteine are metabolically related to the methionine pathway: serine being the precursor in the synthesis of folate, which is the methyl donor for the synthesis of methionine and cysteine from the precursor of cystathionine, which is intermediate in methionine synthesis [59]. Methionine biosynthesis results from the coupling of homocysteine and a methyl group, but can be accomplished via two distinct pathways [55,60]. The E. coli K-12 methionine biosynthesis pathway http://biocyc.org/ECOLI/organism-summary?object=ECOLI\&detail-level=3 has been schematically presented by EcoCys [61], a member of BioCys database collection (http://biocyc.org/publications.shtml), and is available via SRI International Pathway Tools, version 
13.5 [62]. A summary of the consecutive reactions, participating genes and respective products is given in Table 1. The nonfolate branch of the methionine pathway includes metA, metB, met $C, \operatorname{met} H$, and $m e t K$ and the folate branch is comprised of $m e t F$ and $m e t E$ which are all negatively controlled by the metJ repressor system [73]. The final methyl transfer is catalyzed by either a $\mathrm{B}_{12}$-dependent methyltransferase (metH gene product) or a non- $\mathrm{B}_{12}$-methyl transferase (metE product). The metabolic intermediate, 5-methyltetrahydrafolate, encoded by the metF, provides the methyl group for both enzymes to attach. This is a convergence point through which the cells are able to balance the requirement for protein synthesis, methylation reactions, and nucleic acid synthesis on several levels and to regulate the pathway flow of methyl units [73]. Once methionine is formed, it is metabolized to S-adenosylmethionine (AdoMet) in the presence of ATP and AdoMet synthetase, a met $K$ gene product [74-76].

The regulation of the methionine biosynthetic pathway consists of positive and negative feedback mechanisms depending on methionine availability and $\mathrm{B}_{12}$. For example, MetE biosynthesis is autoregulated via a negative feedback loop. It can also function as an antagonist of the met $R$ gene product, by either interfering directly in the activation mechanism or by repressing met $R$ expression [73,77,78]. Alternatively, the activation depends not only on the presence of a functional MetR but also on a coactivator. A functional met $F$ gene is required for vitamin $\mathrm{B}_{12}$ - mediated repression of $m e t E$ gene, and 5-methyltetrahydrofolate may be involved in a negative feedback repression. Inactivation of the metE gene allows for accumulation of the methionine intermediates O-succinylhomoserine, cystathionine, homocysteine, and 5-methyltetrahydrafolate [60,75].

Table 1. Summary of genes which participate in methionine biosynthesis and regulation.

\begin{tabular}{|c|c|c|c|}
\hline Gene & Product & Reaction/Function & Reference \\
\hline \multicolumn{4}{|c|}{ Methionine biosynthesis } \\
\hline metA & $\begin{array}{l}\text { homoserine } \mathrm{O}- \\
\text { transsuccinylase }\end{array}$ & $\begin{array}{l}\text { L-homoserine + succinyl-CoA }<==>\text { O-succinyl-L- } \\
\text { homoserine }+ \text { coenzyme A }\end{array}$ & [63] \\
\hline $\operatorname{met} B$ & Cystathionine ã-synthetase & $\begin{array}{l}\text { L-cysteine }+ \text { O-succinyl-L-homoserine }<==>\text { succinate }+ \\
\text { L-cystathionine }+\mathrm{H}+\end{array}$ & {$[64]$} \\
\hline metC & cystathionase & $\begin{array}{l}\mathrm{L} \text {-cystathionine }+\mathrm{H} 2 \mathrm{O}<==>\text { pyruvate }+ \text { ammonia }+\mathrm{L} \text { - } \\
\text { homocysteine }+\mathrm{H}+\end{array}$ & {$[65]$} \\
\hline metH & $\begin{array}{l}\text { Cobalamin-dependent } \\
\text { tetrahydropteroylglutamate } \\
\text { methyltransferase }\end{array}$ & $\begin{array}{l}\text { L-homocysteine }+5 \text {-methyltetrahydrofolate }<==>\text { L- } \\
\text { methionine }+ \text { tetrahydrofolate }\end{array}$ & {$[66]$} \\
\hline metE & $\begin{array}{l}\text { Cobalamin-independent } \\
\text { tetrahydropteroyltriglutamate } \\
\text { methyltransferase }\end{array}$ & $\begin{array}{l}\text { L-homocysteine }+5 \text {-methyltetrahydropteroyltri-L- } \\
\text { glutamate }<=>\text { L-methionine }+ \text { tetrahydro-pteroyltri-L- } \\
\text { glutamate }\end{array}$ & {$[67]$} \\
\hline $\operatorname{yag} D$ & homocysteine methyltransferase & $\begin{array}{l}\text { L-homocysteine }+ \text { S-adenosyl-L-methionine }<==>\text { L- } \\
\text { methionine }+ \text { S-adenosyl-L-homocysteine }+\mathrm{H}+\end{array}$ & {$[68]$} \\
\hline metK & $\begin{array}{l}\text { methionine } \\
\text { adenosyltransferase }\end{array}$ & $\begin{array}{l}\text { Catalyzes the formation of the sulfonium } \\
\text { compound S-adenosylmethionine from } \\
\text { methionine }\end{array}$ & {$[70]$} \\
\hline
\end{tabular}


Table 1. Cont.

\section{Methionine biosynthesis regulation}

\begin{tabular}{lll} 
metR & $\begin{array}{l}\text { DNA-binding transcriptional } \\
\text { activator, homocysteine- }\end{array}$ & Transactivate $m e t A$, metE, and metH \\
binding & & \\
metJ & $\begin{array}{l}\text { S-adenosylmethionine } \\
\text { transcriptional repressor }\end{array}$ & $\begin{array}{l}\text { Represses transcription from associated } \\
\text { promoter }\end{array}$ \\
\hline
\end{tabular}

The first unique step in bacterial methionine biosynthesis involves the activation of homoserine, which in $E$. coli is accomplished through a succinylation reaction catalyzed by homoserine transsuccinylase (HTS). The activity of this enzyme is closely regulated in vivo and therefore represents a critical control point for cell growth and viability [79]. Born and Blanchard [80] cloned homoserine transsuccinylase from $E$. coli and demonstrated that the enzyme generates a complex with the succinyl group of succinyl-CoA before transferring it to homoserine to form the final product, O-succinylhomoserine. The enzyme can be inhibited by iodoacetamide in a pH-dependent manner which suggests the presence of cysteine in the active site that forms a succinyl-cysteine intermediate during enzymatic turnover. In E. coli, HTS is not only a key regulator of methionine biosynthesis but also of the bacterial growth at elevated temperatures [81]. E. coli growth is impaired at temperatures above $44{ }^{\circ} \mathrm{C}$ due to the instability of HTS. According to Biran et al. [79], the instability of the protein is determined by the amino-terminal part of the protein, and its removal or substitution by the $\mathrm{N}$-terminal part of beta-galactosidase confers stability. Mordukhova et al. [82] reported that two amino acids in the enzyme, namely isoleucine 229 and asparagine 267, are responsible for HTS instability and their substitution leads to stabilization of HTS molecule and improved bacterial growth at elevated temperature. MetA is controlled by the expression of met $J$ [83].

MetE, a zinc-containing monomer, transfers the methyl group of $\mathrm{N}^{5}$-methyl-tetrahydrofolic to the thiolate group of homocysteine $[68,75,78]$. Several mechanisms for repression of metE exist. The interaction between methionine as S-adenosylmethionine with MetJ leads to a corepression of metE through a negative feedback loop [75]. The absence of MetR can also repress metE. MetR and MetE are of similar size and exist relatively in the same location but result from transcription in opposite directions [77]. MetR is a transactivator of both metE and metH gene [75,77,78]. Homocysteine coactivates both the expression of the $m e t R$ gene and the MetR stimulation of metE expression.

The vitamin $\mathrm{B}_{12}$-mediated repression of the met $E$ gene in $E$. coli requires the $\mathrm{B}_{12}$-dependent transmethylase, a product of the metH gene. It has been proposed that the MetH- $\mathrm{B}_{12}$ holoenzyme complex is involved directly in the repression mechanism [55,73,75]. According to Wu et al. [84], however, $\mathrm{B}_{12}$-mediated repression of the metE gene derives primarily from a loss of MetR-mediated activation due to depletion of the coactivator homocysteine, rather than a direct repression by the MetH-B 12 holoenzyme. MetH has a higher constant of Michaelis-Menten $\left(\mathrm{K}_{\mathrm{m}}\right)$ than MetE, which is compensated by the very strong expression of the metE gene [68]. $\mathrm{N}^{5}$-methyl- $\mathrm{H}_{4}$-folate transfers a methyl unit to the MetH holoenzyme where it is subsequently attached to homocysteine $[55,68,75,78]$. The cobalamin-independent methyltransferase (MetE) shares no similarity with the sequence of the cobalamin-dependent protein (MetH), suggesting that the two have arisen by convergent evolution [85]. 
The $m e t F$ gene codes for $\mathrm{N}^{5}$-methyl- $\mathrm{H}_{4}$-folate and regulates $m e t E$ in an indirect way. $\mathrm{N}^{5}$-methyl- $\mathrm{H}_{4}$-folate is required for the transfer of a methyl group to the $\mathrm{B}_{12}$ within the MetH holoenzyme forming a methyl-B ${ }_{12}$ enzyme; the catalytically active methylated form of the MetH protein regulates metE expression [55,75,77,78]. Regulation by MetJ may occur more readily because of the existence of 5 met boxes in metF's promotor region making it more sensitive than the other met genes to small increases of AdoMet that might occur in $\mathrm{B}_{12}$ grown cells [75].

YagD is a third methionine synthase in E. coli. YagD is a zinc-dependent methyltransferase with a catalytic mechanism similar to MetH and synthesizes methionine from S-methylmethionine or S-adenosylmethionine and homocysteine. YagD does not contribute to the utilization of methionine sulfoxide as methionine sulfoxide is converted to methionine via reduction. YagD is subject to regulation by the MetJ-S-adenosyl-methionine system [68].

All met genes are regulated by MetJ. MetJ protein binds to a specific DNA region, met box, which is present in all met genes except met $H$. The met box region is a sequence with dyad symmetry (TGAA ... TTCA) and produces a helical region containing four leucine residues seven amino acids apart. This motif is called a leucine zipper and has been proposed to play a role in protein dimerization that is required for DNA bindings. MetJ can bind to this region and prevent the transcription of most of the met genes (metA, metBL, metC, metF, metJ, metR, and metE) [55,59,71,74]. The interaction of the MetJ protein with the met operator region is markedly enhanced by the presence of AdoMet.

\section{Bacterial Transport of Methionine}

Although E. coli prototroph cells are capable of synthesizing methionine de novo, they can also acquire external methionine or methionine analogs to satisfy cellular needs for either methionine or sulfur which reflects the high flexibility of the organism under a wide range of environmental conditions. The activity of methionine transport systems in E. coli is influenced by the concentrations of both external and internal methionine pools [86]. Cells with increased internal methionine pool or pre-exposed to excess of external methionine exhibit decreased rates of methionine uptake. Conversely, starvation for methionine in a methionine auxotroph can increase the rate of external methionine transport [86].

At least two transport systems for methionine exist in E. coli. The high affinity transport system (metD) has a $\mathrm{K}_{\mathrm{m}}$ of approximately $10^{-7} \mathrm{M}$ and is responsible for the uptake of L- and D- methionine isomers [87]. MetD is an ABC transporter with $\mathrm{Abc}$ the ATPase, YaeE the permease, and YaeC the likely substrate binding protein. The expression of these genes is regulated by L-methionine and MetJ, the common repressor of the methionine regulon. Interestingly, L-methionine inhibits the uptake of D-methionine; however, D-methionine does little to affect the uptake of the L-isomer [88]. By performing competition experiments Kadner [88] established that MetD possesses a distinct substrate-binding site for each stereoisomer. The second system $(m e t P)$ is a low affinity system with a $\mathrm{K}_{\mathrm{m}}$ of approximately $40 \mu \mathrm{M}$ and can transport L-methionine but not the D-isomer [88,89]. By using various deletion mutants, Merlin et al. [87] observed that only mutants with active MetD were able to grow on D-methionine.

Methionine can be transported across a concentration gradient (a temperature sensitive uptake process) with the assistance of MetD [90]. The accumulation against a concentration gradient and the temperature influence of the uptake indicates that methionine enters bacterial cells through active 
transport, which is an energy-dependent process. When starved of methionine, the rate of uptake of methionine is faster than those grown with methionine [91]. Both systems are regulated by the level of the internal methionine pool of the bacterium and differ in affinity by a factor of at least 400 -fold [86,88,91]. In E. coli, the methionine, transported into the cells, accumulates in the form of AdoMet rather than as free methionine.

Active transport can be completely eliminated in the presence of glucose with the presence of azide and fluoride [86,91]. In the absence of glucose, cells could still accumulate methionine less efficiently. The methionine analogs that inhibit uptake required the $-\mathrm{S}$ (or Se)-CHS group [91]. The initial rate of uptake of L-methionine was poorly affected by the addition of $\alpha$-keto- $\lambda$-methiol-butyrate, D-methionine, or methionine sulfoxide when they were added simultaneously with the substrate. However, methionine transport was reduced in cells exposed to analogs and methionine variations prior to the addition of a substrate [86].

\section{Genetic Strategies for Construction of E. Coli Mutants for Methionine Bioassays}

\subsection{General Strategies}

Understanding methionine biosynthesis and transportation in $E$. coli is a prerequisite for constructing accurate and specific microbial biosensors for methionine estimation. An E. coli microbial bioassay approach for methionine quantification necessitates using an auxotrophic strain for methionine which is incapable of biosynthesizing this amino acid on its own. As discussed in the previous sections, mutants, currently in use for the purpose of methionine quantification, have been developed and isolated after exposure to a chemical mutagen. However, the disadvantage of the imprecise nature of chemical mutagenesis requires other approaches for generation of mutants that are more specific and efficient.

To avoid the hit and miss nature of broad spectrum mutagenesis approaches such as those involving addition of chemical mutagens requires a strategy that targets a specific site on the genome without alteration of the remainder of the genome. Such approaches are more likely to result in phenotypes that are exclusively linked to a specific genetic modification rather than the collective accumulation of several mutations some of which may not be related to the gene(s) of interest. The problem with multiple mutations is not only the risk of unpredictable reversion of the phenotype of interest but a less robust mutant that does not grow as well under the selective conditions required for a particular assay. In the past few years, genetic tools have been developed that harness the utility of biological systems such as transposons that can more directly interact with the bacterial chromosome at specific sites.

Transposons are versatile tools for genetic manipulation and analysis. These are DNA sequences that can be mobilized into bacterial chromosome by a recombination process that is catalyzed by an enzyme, called transposase. In contrast to chemical mutagenesis, insertion of a transposon in the bacterial genome causes complete disruption of the gene of interest and results in non-leaky phenotypes that are specifically linked to the mutated gene [92]. This approach is particularly useful where the function of all the genes in the bacterial genome is not known or the biosynthetic pathway of the analyte of interest is complicated or bypassed. Transposon engineering was used by McAdam et al. [93] to mutate Mycobacterium bovis BCG, a member of the slow-growing $M$. tuberculosis complex. Two auxotrophs for leucine and one for methionine were isolated from the 
library of transposon insertions and used to study the functionality of the respective genes. The random insertion of transposon Tn4560 into Streptomyces tendae ATCC 31160 resulted in identification of six genes involved in the biosynthesis of nikkornycin, a nucleoside-peptide chitin synthase inhibitor [94]. The scope of application of transposon mutagenesis techniques was increased by Kwon and Ricke [95] and Kwon et al. [96] when they developed an approach for the identification of transposon location in the bacterial genome based on the amplification of transposon flanking regions using polymerase chain reaction (PCR).

Deletion of specific gene(s) which abolishes the biosynthetic capability of the bacteria for certain amino acids is an alternative approach to transposon mutagenesis. This technique is applicable when the sequence of the gene to be deleted is known. Four individual $(\triangle g \ln A 1, \Delta g \ln A 2, \Delta g \ln A 3$, and $\Delta g \ln A 4)$ and one triple mutant $(\triangle g \ln A 1 E A 2)$ of Mycobacterium tuberculosis were generated by deletion to investigate the roles of glutamine synthetase enzymes in the nitrogen metabolism of this specific bacterium [97]. Tryptophan auxotrophy in Leptospira meyeri was achieved by deletion of the tryptophan biosynthetic gene trpE via homologous recombination [98]. Li and Ricke [99] were able to completely delete $l y s A$ in E. coli K12 by using a linear DNA which contained at both ends 50 bp sequences homologous to upstream and downstream sequences of $l_{s} A$. The $\operatorname{lys}_{s} A$ encoded for diaminopimelic acid decarboxylase and is a key enzyme in lysine biosynthetic pathway in E. coli $\mathrm{K} 12$ [99]. The recombinant strain behaved as an auxotroph for lysine and was not able to grow in minimal medium without lysine supplementation. The E. coli $\mathrm{K} 12 \Delta \operatorname{lys} A$ growth response to increasing concentrations of lysine was found to be linear, which is a must for the purpose of lysine quantification in feed-derived proteins. In fact, after being converted into a fluorescent biosensor, the strain was successfully used to quantitatively assess lysine in feed ingredients and complete diets [19].

\subsection{Generating specific E. coli Methionine Auxotrophs}

Identifying a specific gene from the biosynthetic pathway of methionine in E. coli in which a deletion could result in methionine auxotroph phenotype is not straightforward. Due to the versatility in methionine biosynthetic pathway, only mutations in certain genes in the met regulon would result in auxotrophy for methionine and not for any of the pathway intermediates or precursors. For example, met $L$ mutants can grow on homoserine while met $B L$ mutants can propagate on both cystathionine and homoserine [101]. While studying mutations that influenced the methionine biosynthetic pathway, Mulligan et al. [55] observed that deficiencies in metA and metB resulted in growth requirements for homosysteine and cystathionine, and a mutation in metE was overcome by $\mathrm{B}_{12}$ supplementation. Insertions in met $L$ and met $H$ also did not result in methionine auxotrophy. In the same study, met $F$ was the only gene which sufficiently abolished biosynthesis functions to ensure a requirement for external methionine for bacterial growth. In Streptomyces lividans, the disruption of a gene encoding for 5,10-methylenetetrahydrofolate reductase which was found to be highly homologous to E. coli MetF, also resulted in methionine auxotrophy [102].

In contrast to other amino acid mutants of $E$. coli which require the L-form for growth, cys and met mutants are capable of using either isomer of cysteine or methionine [103]. D-Methionine is not bioactive and cannot be directly incorporated into protein biosynthesis. Therefore, the utilization of D-methionine for L-methionine is justifiable only if the D-form of this amino acid is ultimately transformed into L-methionine. According to Cooper [104,105], conversion of D- to L-methionine in 
E. coli is possible and occurs via oxidative deamination and subsequent transamination of the keto-methionine product of the former reaction. By using ultraviolet irradiation, Cooper [105] was able to generate a mutant incapable of growing on D-methionine. The locus of the D-methionine utilization was mapped at approximately 2 min away from lac region toward threonine and leucine. Therefore, to make an $E$. coli biosensor specific for growth on L-methionine would require an addition to disabling the L-methionine biosynthesis genes as well as the genes responsible for conversion of other forms such as D-methionine transformation to L-methionine. Another approach may be possible now that the structure and allosteric regulation of the high-affinity E. coli methionine ABC transporter is better understood [106] and manipulation of methionine transport may offer a more precise targeting of the relationship between intracellular L-methionine transport and external concentration of different forms of methionine.

\section{Detection Modes for Methionine Microbial Biosensors.}

As analytical tools, microbial biosensors are genetically engineered to produce a measurable signal in response to the compound of interest. These signals include but are not limited to light emission, reflection, fluorescence, or absorption. Although their function is based on different principles, a common feature is the proportionality between the intensity of the signal and the concentration of target analyte [107]. The choice of an appropriate detection system is an important point since each detection mode possesses advantages and disadvantages which are summarized in Table 2. Several detection methods for detecting microbial responses exist for potential implementation in respect to the microbiological assay for methionine quantification.

Table 2. Detection systems for microbial assays.

\begin{tabular}{|c|c|c|}
\hline Detection Systems & Characteristics & Reference \\
\hline Optical Density (OD) & $\begin{array}{l}- \text { Economical } \\
- \text { Reliable } \\
\text {-Easy to use }\end{array}$ & {$[111]$} \\
\hline â-galactosidase & $\begin{array}{l}\text { - More sensitive than OD } \\
\text { - Requires more steps }\end{array}$ & [108] \\
\hline Luminescence & $\begin{array}{l}\text {-10X more sensitive than OD } \\
\text { - Requires aldehyde to initiate luminescence } \\
\text { - Expensive }\end{array}$ & [109] \\
\hline Fluorescence & $\begin{array}{l}\text { - Same advantages as luminescence } \\
\text { - Less expensive detection } \\
\text { - Self contained assay: no reagents added }\end{array}$ & {$[110]$} \\
\hline
\end{tabular}

\subsection{Optical Density}

Measuring optical density (OD) is a common approach to monitor bacterial growth and is thoroughly reviewed by Kavanagh in [111]. The readings provided by the spectrophotometer correlate directly with the concentration of bacteria in the test media. A non-inoculated tube with media is used to calibrate the spectrophotometer as a representative blank or "zero" value. A nutrient medium is 
inoculated with the E. coli bacterial suspension, incubated at $37^{\circ} \mathrm{C}$, and the growth response of the test organism is measured hourly. Over time the turbidity/cell number is calculated and ultimately plotted to determine a linear response. The optical density values that constitute the linear slope gradually increase as the concentration of test nutrient increases.

The theoretical aspects of photometry have been extensively described elsewhere [111]. Although OD measurements require minimal technical effort and are relatively inexpensive there are several drawbacks for their use in quantifying nutrients from complex oranic matrices such as animal feeds and feed ingredients. To prevent any potential alternations of methionine availability, autoclaving or heat treatment of feed samples should be avoided. Therefore, the primary problem is the contribution of nonspecific microflora growth that results in OD increases, not corresponding to different concentrations of the nutrient being quantified by the assay organism. Erickson et al. [112] were able to overcome this with the use of an antibiotic-based selective media which exclusively supported the growth of the E. coli lysine bioassay organism. Froelich et al. [113] tested a medium containing a cocktail of antibiotics and antifungal agents and demonstrated that they did not alter growth kinetics of a methionine $E$. coli auxotroph in response to various methionine concentrations when compared to growth responses of the same strain of E. coli grown without antibiotics. Although the use of antibiotics suppress background microflora sufficiently to allow for short term bioassay measurements eventually background microflora can overcome antibiotic inhibition of growth. Consequently, if detection based on OD alone requires longer assay times, background microflora would need to be eliminated by sterilization of the feed matrix. Sterilization, particularly by thermal processes adds to the uncertainty of the accuracy of the amino acid assay by potentially altering their respective availability and any resulting measurements would no longer reflect the original values of the animal feeds being assayed.

\section{2. $\beta$-galactosidase}

The measurement of $\beta$-galactosidase expression historically is a well-understood, easily measured and reliable method for examining bacterial genetics and understanding fundamentals of gene regulation [114]. The $\beta$-galactosidase enzyme assay has also been used as an indirect method of microbial detection and quantitation and is more sensitive than OD [108]. The E. coli lac operon enables the organism to metabolize lactose as a carbon source. This lac operon is translated at a constant rate when lactose is present in the media [115]. Therefore, the enzyme concentration of lysed cells can be directly correlated with the total bacterial cell count. $\beta$-galactosidase assay was successfully used by Hitchens et al. [45] to quantify the bioavailability of cysteine, methionine, threonine, and tryptophan in 17 foods. To overcome the lack of exoproteolytic activities in E. coli, the food matrices were enzymatically digested with pronase and further subjected to analysis with the respective auxotrophic bacterial strain. The accuracy of the $\beta$-galactosidase assay was evaluated by comparison of the data to the amino acid estimates in the same food-derived proteins obtained by a chemical assay. Spearman rank correlation coefficients for the two methods were significant and found to be as follows: cysteine (0.61), methionine (0.95), threonine (0.64), and tryptophan (0.85). Thus, Hitchens et al. [45] and earlier Tuffnell and Payne [108] demonstrated that $\beta$-galactosidase biosynthesis correlated to the concentrations of the amino acid needed by the auxotrophic bacterial cells for growth and could be accurately used in the quantification of methionine, tryptophan, and 
lysine bioavailability. However, the $\beta$-galactosidase-based assay requires more steps than an OD assay. It is disruptive and is not appropriate for kinetic studies. More importantly as with OD measurements, there is a risk of nonspecific background microflora contributing to overall $\beta$-galactosidase assay response as several organisms possess this enzyme. Therefore, a key requirement for any detection system to be used is that it is sufficiently unique versus the typical native microflora already present on the animal feed matrix.

\subsection{Luminescence}

Compared to $\beta$-galactosidase, luminescence is a more recent detection approach and has been routinely used in the generation of bacterial biosensors. This method allows the detection of viable cells through a quantum measurement to indirectly enumerate cells. A bioluminescent signal can not only be coupled to bacterial growth response to accurately measure levels of the respective nutrient limiting bacterial growth but is 10 - fold more sensitive than OD [46,109,116] and considerably more sensitive than $\beta$-galactosidase. While testing the efficiency of both firefly luciferase and $\beta$-galactosidase as reporters in developing vaccine virus, Rodrigues et al. [117] established that the luciferase assay was 1,000 -fold more sensitive than that of $\beta$-galactosidase. The limit of detection of luminescence produced by the action of luciferase was found to be approximately one infected cell in a background of a million noninfected cells.

In E. coli, bioluminescence does not occur and must be acquired via genetic modifications [118,119]. Luminescence is accomplished by the introduction of the lux $A B$ genes via plasmid or chromosomal insertion. Cells are subsequently grown in the test media and a chemical reagent is required to induce the bioluminescent phenotype of the inserted sequence. The production of light lasts only minutes (seconds in flash luminescence) before destabilization of the exogenous reagent. This is a shortcoming of luminescence technology and has led to genetic development of longer lasting luminescence and reagent-less requiring strains. The bioluminescence assay response is measured with a flash luminescence luminometer and requires addition of autoinducer [46,116] and therefore, it is not possible to continuously monitor bacterial cell population increases during exponential growth. In order to quantify luminescence, expensive detection devices must be purchased [46,116]. However, Froelich et al. [120] demonstrated with a bioluminescent $E$. coli methionine auxotroph that, although the growth kinetics between the transformed strain and a nonplasmid carrying auxotroph were somewhat different, the OD-based standard curves between the two strains were similar. This indicates that even in the absence of available luminescent detection equipment such strains could still be used in a conventional OD-based assay with the advantage being that they could be used for luminescent based assays when the opportunity for using such equipment is made available.

\subsection{Fluorescence}

A similar assay method to luminescence is fluorescence. One advantage of fluorescence over luminescence is that it is less expensive to detect and is a self-contained assay, requiring no additional reagents [121]. Fluorescence occurs naturally in chemicals that resonate (a carbon chain with alternating single and double bonds) [122]. It also occurs in a protein referred to as Green Fluorescent Protein (GFP) that originally was produced in jellyfish (Aequorea victoria), but the DNA encoding 
sequence has been isolated and incorporated via transgenics (the genetic translocation of genes from one species to another, i.e., placing $g f p$ from jellyfish into a eukaryotic strain) [123]. Once incorporated, either through transformation of a gene system on a vector or directly incorporated in DNA of the test organism, the fluorescent protein is concomitantly synthesized with other cell proteins. The assay then requires a spectrofluorometer that can excite the engineered organism's new protein and detect emitted light at a different wavelength [110,124]. Just as with OD, the value are recorded over time and graphed linearly over time and concentration.

Originally discovered in Aequorea victoria, two proteins were found within this jellyfish that had luminescent/fluorescent capabilities. The first was aequorin that emitted blue light with the presence of $\mathrm{Ca}^{++}$(luminescence). The second was the green fluorescent protein which when excited could be detected on a fluorometer (fluorescence) [125]. Tsien [122] described the general molecular weight of most GFP forms to be approximately $27 \mathrm{kDa}$. An advantage of the use of $g f p$ as a reporter gene is its structural stability. The eleven beta strands surround and protect the chromophore that is positioned near the geometric center of a "beta can", which protects the chromophore from temperature, acid, and oxidation. Its normal excitation peak is at $395 \mathrm{~nm}$ with a minor peak at $475 \mathrm{~nm}$ and emission peaks at $508 \mathrm{~nm}$ [122]. It does not require any additional substrates or reagents to fluoresce, and thus sample perturbation and destruction are avoided [126]. Froelich et al. [127] successfully transformed an E. coli methionine auxotroph with a plasmid encoding for a green fluorescent protein and demonstrated that it could be used to quantify methionine in several representative animal feed ingredients. However, some variation between OD_based measurements and fluorescent measurements were noted suggesting some potential interference with fluorescent measurements.

Some artifacts have to be taken into consideration when detecting the GFP chromophore. Media and feeds may contain aromatic and resonating conjugate carbon chains that may also fluoresce. Some of them have emission spectrum overlapping the emission spectrum of GFP (350 to $550 \mathrm{~nm}$ ). This often leads to low signal to noise ratios, decreased emission intensity and occasionally complete inability to detect the fluorescence emitted by GFP [128]. To correct for this, a simple excitation filter that allows light to pass at wavelengths higher than $350 \mathrm{~nm}$ is used in conjunction with an emissions bandpass filter that allows only light with certain wavelength to pass. Heim and Tsien [129] using specific optical filters detected three different forms of GFP simultaneously in samples of viable bacteria. In addition, GFP variants with different emission spectra were created to overcome either the low intensity of the emission signal or the background fluorescence of various compounds. The resulting GFP mutants are characterized with different excitation/emission spectra, brighter fluorescence, higher solubility, and more even distribution throughout the cytoplasm than the wild type [130]. These mutants allow the monitoring of multiple species of bacteria simultaneously in a complex microbial community. However, Patterson et al. [131] implied that no single variant was appropriate for all applications but that each of them offers advantages and disadvantages when investigating viable cells.

There are some issues associated with fluorescence assay which must be accounted for such as autofluorescence from matrices that naturally fluoresce. By studying autofluorecence capacity of feed ingredients including soybean meal, cottonseed meal, meat and bone meal, Chalova et al. [132] observed that hydrolyzed feed proteins in concentrations up to $0.1 \mathrm{mg} / \mathrm{ml}$ did not interfere with the fluorescence of Gfpmut3 [133] which was used as a reporter in an E. coli whole cell-based lysine 
biosensor. Nonhydrolyzed soybean meal and cottonseed meal did not exhibit detectable background fluoorescence up to $2 \mathrm{mg} / \mathrm{ml}$. The same authors demonstrated the advantages of the constructed $g f p$ based biosensor in the quantification of bioavailable lysine in the feed samples when contaminated with E. coli.

The second possible problem is light scatter in the fluorometer. By simply diluting the sample to an OD of 0.1 or less, absorption artifacts and secondary inner filter affects can be avoided. This also prevents light scatter because the density of the sample is lower. Other techniques to lower light scatter should be checked with a blank made from media to determine if scatter is occurring. Finally, the existence of possible quenchers such as other fluorophores which may lower or lose quantum yield can be problematic. This can be corrected with the application of several equations depending on the cause [110].

\section{Conclusions}

In conclusion, microbial sensors for methionine quantification in feed and feed ingredients are an alternative to animal assays because they have the advantage of being simpler, more rapid, and cost efficient. Versatile tools in molecular biology combined with current knowledge of $E$. coli genetics favor the generation of appropriate and successful constructs that may serve as methionine biosensors. However, more work needs to be done in understanding the bacterial genome to better target gene(s) that lead to generation of methionine auxotroph exhibiting a single phenotype. The wide variety of available detection modes should facilitate the choice of a reporting system which will contribute to the simplified operation and identification of a biosensor's emitted signal.

\section{Acknowledgments}

This review was supported by Hatch Grant H8311 administered by the Texas Agricultural Experimental Station and Texas Advanced Technology program grant \#000517-0220-2001 (Texas Higher Education Board, Austin, TX). C. A. Froelich, Jr. was partially supported by a Texas Public Education Grant (Texas Higher Education College Board, Austin, TX).

\section{References}

1. Schwab, C.G. Rumen-protected amino acids for dairy cattle: Progress towards determining lysine and methionine requirements. Anim. Feed Sci. Technol. 1996, 59, 87-101.

2. Boisen, S.; Hvelplund, T.; Weisbjerg, M.R. Ideal amino acid profiles as a basis for feed protein evaluation . Livest Prod. Sci. 2000, 64, 239-251.

3. Webel, D.M.; Baker, D.H. Cystine is the first limiting amino acid for utilization of endogenous amino acids in chicks fed a protein-free diet. Nutr. Res. 1999, 19, 569-577.

4. Bunchasak, C. Role of dietary methionine in poultry production. J. Poult. Sci. 2009, 46, 169-179.

5. Brosnan, J.T.; Brosnan, M.E. The sulfur-containing amino acids: an overview. J. Nutr. 2006, 136, 1636S-1640.

6. Kalbande, V.H.; Ravikanth, K.; Maini, S.; Rekhe, D.S. Methionine supplementation options in poultry. Intern. J. Poult. Sci. 2009, 8, 588-591. 
7. Dilger, R.N.; Kobler, C.; Weckbecker, C.; Hoehler, D.; Baker, D.H. 2-Keto-4-(Methylthio) butyric acid (keto analog of methionine) is a safe and efficacious precursor of L-methionine in chicks. J. Nutr. 2007, 137, 1868-1873.

8. Daenner, E.; Bessei, W. Influence of supplementation with liquid DL-methionine hydroxy analogue-free acid (alimet) or DL-methionine on performance of broilers. J. Appl. Poult. Res. 2003, 12, 101-105.

9. Kim, W.K.; Froelich Jr., C.A.; Patterson, P.H.; Ricke, S.C. The potential to reduce poultry nitrogen emissions with dietary methionine or methionine analogues supplementation. World Poult. Sci. J. 2006, 62, 338-353.

10. Klasing, K.C.; Austic, R.E. In Nutritional diseases. In Diseases of Poultry; Saif, Y.M., Ed.; Iowa State Press: Ames, IA, USA, 2003; p. 1027.

11. Baker, D.H. Comparative species utilization and toxicity of sulfur amino acids. J. Nutr. 2006, 136, 1670S-1675.

12. Pesti, G.M.; Benevenga, N.J.; Harper, A.E.; Sunde, M.L. The effects of high dietary protein and nitrogen levels on the preformed methyl group requirement and methionine-induced growth depression in chicks. Poult. Sci. 1981, 60, 425-432.

13. Skoog, D.A.; Holler, E.F.; Nieman, T. A. Principles of Instrumental Analysis; Saunder College Publishing: Ft. Worth, TX, USA, 1998.

14. Nielson, S.S. In Food analysis; Aspen Production: Gaithersburg, MD, USA, 1998.

15. Parsons, C.M.; Castanon, F.; Han, Y. Protein and amino acid quality of meat and bone meal. Poult. Sci. 1997, 76, 361-368.

16. D'Mello, J.P.F. Response of growing poultry to amino acids. In Amino Acids in Animal Nutrition; D’Mello, J.P.F., Ed.; CABI Publishing: Wallingford, CT, USA, 2003; p. 237.

17. Cork, L.C.; Clarkson, T.B.; Jacoby, R.O.; Gaertner, D.J.; Leary, S.L.; Linn, J.M.; Pakes, S.P.; Ringler, D.H.; Strandberg, J.D.; Swindle, M.M. The costs of animal research: origins and options. Science 1997, 276, 758-759.

18. Froelich, C.A.; Ricke, S.C. Rapid bacterial-based bioassays for quantifying methionine bioavailability in animal feeds: a review. J. Rapid Meth. Autom. Microbiol. 2005, 13, 1-10.

19. Chalova, V.I.; Kim, W.K.; Woodward, C.L.; Ricke, S.C. Quantification of total and bioavailable lysine in feed protein sources by a whole-cell green fluorescent protein growth-based Escherichia coli biosensor. Appl. Microbiol. Biotechnol. 2007, 76, 91-99.

20. D’Souza, S.F. Microbial biosensors. Bios. Bioelectr. 2001, 16, 337-353.

21. Lei, Y.; Chen, W.; Mulchandani, A. Microbial biosensors. Anal. Chim. Acta 2006, 568, 200-210.

22. Mello, L.D.; Kubota, L.T. Review of the use of biosensors as analytical tools in the food and drink industries. Food Chem. 2002, 77, 237-256.

23. Odaci, D.; Timur, S.; Telefoncua, A. A microbial biosensor based on bacterial cells immobilized on chitosan matrix. Bioelectrochemistry 2009, 75, 77-82.

24. Couper, J. Application and Construction of Microbial Biosensors in Chemical Forensics; Dissertation, Victoria University of Wellington: Wellington, New Zealand, 2008.

25. Mulchandani, P.; Chen, W.; Mulchandani, A. Microbial biosensor for direct determination of nitrophenyl-substituted organophosphate nerve agents using genetically engineered Moraxella sp. Anal. Chim. Acta 2006, 568, 217-221. 
26. Kumar, J.; Jha, S.K.; D’Souza, S.F. Optical microbial biosensor for detection of methyl parathion pesticide using Flavobacterium sp. whole cells adsorbed on glass fiber filters as disposable biocomponent. Biosen. Bioel. 2006, 21, 2105-2100.

27. Tecon, R.; van der Meer, J.R. Bacterial biosensors for measuring availability of environmental pollutants. Sensors 2008, 8, 4062-4080.

28. Tkáč, J.; Gemeiner, P.; Švitel, J.; Benikovský, T.; Šturdík, E.; Vala, V.; Petruš, L.; Hrabárová, E. Determination of total sugars in lignocellulose hydrolysate by a mediated Gluconobacter oxydans biosensor. Anal. Chim. Acta 2000, 420, 1-7.

29. Rotariu, L.; Bala, C.; Magearu, V. New potentiometric microbial biosensor for ethanol determination in alcoholic beverages. Anal. Chim. Acta 2004, 513, 119-123.

30. Luong, J.H.T.; Mulchandani, A.; Groom, C.A. The development of an amperometric microbial biosensor using Acetobacter pasteurianus for lactic acid. J. Biotechnol. 1989, 10, 241-252.

31. Buglass, A.J.; Garnham, S.C. A novel method for the determination of lactic acid. Comparison of lactic acid content of English and North European wines. Am. J. Enol. Vitic. 1991, 42, 63-66.

32. Riedel, K. Microbial biosensors based on oxygen electrodes. In Enzyme and Microbial Biosensors: Techniques and Protocols; Mulchandani, A., Rogers, K.R., Eds.; Humanae Press: Totowa, NJ, USA, 1998; p. 199.

33. Simonian, A.L.; Rainina, E.I.; Fitzpatrick, P.F.; Wild, J.R. A tryptophan-2-monooxygenase based amperometric biosensor for L-tryptophan determination: use of a competitive inhibitor as a tool for selectivity increase. Bios. Bioel. 1997, 12, 363-371.

34. Ingraham, J.L.; Maaløe, O.; Neidhardt, F.C. Growth of the Bacterial Cell; Sinauer Associates, Inc.: Sunderland, MA, USA, 1983.

35. Blattner, F.R. The complete genome sequence of Escherichia coli K-12. Science 1997, 277, 1453-1462.

36. Ptitsyn, L.R.; Horneck, G.; Komova, O.; Kozubek, S.; Krasavin, E.A.; Bonev, M.; Rettberg, P. A biosensor for environmental genotoxin screening based on an SOS lux assay in recombinant Escherichia coli cells. Appl. Environ. Microbiol. 1997, 63, 4377-4384.

37. Fiorentino, G.; Ronca, R.; Bartolucci, S. A novel E. coli biosensor for detecting aromatic aldehydes based on a responsive inducible archaeal promoter fused to the green fluorescent protein. Appl. Microbiol. Biotechnol. 2009, 82, 67-77.

38. Prest, A.G.; Winson, M.K.; Hammond, J.R.M.; Stewart, G.S.A.B. The construction and application of a lux-based nitrate biosensor. Lett. Appl. Microbiol. 1997, 24, 355-360.

39. Willardson, B.M.; Wilkins, J.F.; Rand, T.A.; Schupp, J.M.; Hill, K.K.; Keim, P.; Jackson, P.J. Development and testing of a bacterial biosensor for toluene-based environmental contaminants. Appl. Environ. Microbiol. 1998, 64, 1006-1012.

40. Stocker, J.; Balluch, D.; Gsell, M.; Harms, H.; Feliciano, J.; Daunert, S.; Malik, K.A.; van der Meer, J. R. Development of a set of simple bacterial biosensors for quantitative and rapid measurements of arsenite and arsenate in potable water. Environ. Sci. Technol. 2003, 37, 4743-4750.

41. Chakraborty, T.; Babu, P.G.; Alam, A.; Chaudhari, A. GFP expressing bacterial biosensor to measure lead contamination in aquatic environment. Curr. Sci. 2008, 94, 800-805.

42. Eshkenazi, I.; Maltz, E.; Zion, B.; Rishpon, J. A three-cascaded-enzymes biosensor to determine 
lactose concentration in raw milk. J. Dairy Sci. 2000, 83, 1939-1945.

43. Held, M.; Schuhmann, W.; Jahreisc, K.; Schmidt, H. Microbial biosensor array with transport mutants of Escherichia coli K12 for the simultaneous determination of mono-and disaccharides. Biosen. Bioel. 2002, 17, 1089-1094.

44. Krapf, G.; Bode, W. A microbiological assay based on ampicillin-induced lysis of Escherichia coli auxotrophs. Zbl. Bakt. Hyg. , I Abt. Orig. C 1980, 1, 314-319.

45. Hitchins, A.D.; McDonough, F.E.; Wells, P.A. The use of Escherichia coli mutants to measure the bioavailability of essential amino acids in foods. Plant Foods Hum. Nutr. 1989, 39, 109-120.

46. Erickson, A.M.; Diaz, I.B.Z.; Kwon, Y.M.; Ricke, S.C. A bioluminescent Escherichia coli auxotroph for use in an in vitro lysine availability assay. J. Microbiol. Meth. 2000, 40, 207-212.

47. Chalova, V.I.; Sirsat, S.A.; O’Bryan, C.A.; Crandall, P.; Ricke, S.C. Escherichia coli, an intestinal microorganism, as a biosensor for quantification of amino acid bioavailability. Sensors 2009, 9 , 7038-7057.

48. Erickson, A.M.; Li, X.; Woodward, C.L.; Ricke, S.C. Optimisation of enzyme treatment for the degradation of feed proteins for an Escherichia coli auxotroph lysine availability assay. J. Sci. Food Agric. 1999, 79, 1929-1935.

49. Zabala-Díaz, I.B.; Carreon, F.O.C.; Ellis, W.C.; Ricke, S.C. Assessment of an Escherichia coli methionine auxotroph growth assay for quantifying crystalline methionine supplemented in poultry feeds. J. Rapid Methods Auto. Micro. 2004, 12, 155-167.

50. Zabala-Díaz, I.B.; Froelich, C.A.; Ricke, S.C. Adaptation of a methionine auxotroph Escherichia coli growth assay to microtiter plates for quantitating methionine. J. Rapid Methods Auto. Micro. 2003, 10, 217-229.

51. Adelberg, E.A.; Mandel, M.; Chein, C.C.G. Optimal conditions for mutagenesis by N-methyl-N'-nitro-N-nitrosoguanidine in Escherichia coli K12. Biochem. Biophys. Res. Commun. 1965, 18, 788-795.

52. Snyder, L.; Champness, W. Molecular Genetics of Bacterial; ASM Press: Washington, DC, USA, 1997.

53. Kim, C.S.; Wood, T.K. Creating auxotrophic mutants in Methylophilus methylotrophus AS1 by combining electroporation and chemical mutagenesis. Appl. Microbiol. Biotechnol. 1997, 48, 105-108.

54. Wright, B.E.; Minnick, M.F. Reversion rates in a leuB auxotroph of Escherichia coli K-12 correlate with ppGpp levels during exponential growth. Microbiology 1997, 143, 847-854.

55. Mulligan, J.T.; Margolin, W.; Krueger, J.H.; Walker, G.C. Mutations affecting regulation of methionine biosynthetic genes isolated by use of met-lac fusions. J. Bacteriol. 1982, 151, 609619.

56. Froelich, C.A.; Zabala-Díaz, I.B.; Ricke, S.C. Potential rapid bioassay for Alimet ${ }^{\circledR}$ using a methionine Escherichia coli auxotroph. J. Rapid Methods Auto. Micro. 2002, 10, 161-172.

57. Shoveller, A.K.; Moehn, S.; Rademacher, M.; Htoo, J.K.; Ball, R.O. Methionine-hydroxy analogue was found to be significantly less bioavailable compared to DL-methionine for protein deposition in growing pigs. Animal 2009, 77, 427-439. 
58. Feng, Z.; Qiao, S.; Ma, Y.; Wang, X.; Li, X.; Thacker, P.A. Efficacy of methionine hydroxy analog and DL-methionine as methionine sources for growing pigs. J. Anim. Veter. Adv. 2006, 5, 135-142.

59. Michaeli, S.; Mevarech, M.; Ron, E.Z. Regulatory region of the metA gene of Escherichia coli K-12. J. Bacteriol. 1984, 160, 1158-1162.

60. Ahmed, A. Mechanism of repression of methionine biosynthesis in Escherichia coli. Mol. Gen. Genet. 1973, 123, 299-324.

61. Keseler, I.M.; Bonavides-Martinez, C.; Collado-Vides, J.; Gama-Castro, S.; Gunsalus, R.P.; Johnson, D.A.; Krummenacker, M.; Nolan, L.M.; Paley, S.; Paulsen, I.T.; Peralta-Gil, M.; Santos-Zavaleta, A.; Shearer, A. G.; Karp, P. D. EcoCyc: A comprehensive view of Escherichia coli biology. Nucl. Acids Res. 2009, 37, D464-470.

62. Karp, P.D.; Paley, S.; Romero, P. The pathway tools software. Bioinformatics 2002, 18, S1-S8.

63. Arifuzzaman, M., et al Large-scale identification of protein-protein interaction of Escherichia coli K-12. Genome Res. 2006, 16, 686-691.

64. Aitken, S.M.; Kim, D.H.; Kirsch, J.F. Escherichia coli cystathionine $\gamma$-synthase does not obey ping-pong kinetics. Novel continuous assays for the elimination and substitution reactions. Biochemistry 2003, 42, 11297-11306.

65. Awano, N.; Wada, M.; Kohdoh, A.; Oikawa, T.; Takagi, H.; Nakamori, S. Effect of cysteine desulfhydrase gene disruption on L-cysteine overproduction in Escherichia coli. Appl. Microbiol. Biotechnol. 2003, 62, 239-243.

66. Banerjee, R.V.; Johnston, N.L.; Sobeski, J.K.; Datta, Prasanta Matthew, Rowena G. Cloning and sequence analysis of the Escherichia coli metH gene encoding cobalamin-dependent methionine synthase and isolation of a tryptic fragment containing the cobalamin-binding domain. J. Biol. Chem. 1989, 264, 13888-13895.

67. Daniels, D.L.; Plunkett, G.I.; Burland, V.; Blattner, F.R. Analysis of the Escherichia coli genome: DNA sequence of the region from 84.5 to 86.5 minutes. Science 1992, 257, 771-8.-778.

68. Thanbichler, M.; Neuhierl, B.; Bock, A. S-methylmethionine metabolism in Escherichia coli. J. Bacteriol. 1999, 181, 662-665.

69. Saint-Girons, I.; Duchange, N.; Zakin, M.M.; Park, I.; Margarita, D.; Ferrara, P.; Cohen, G.N. Nucleotide sequence of metF, the E. coli structural gene for 5-10 methylene tetrahydrofolate reductase and of its control region. Nucl. Acids Res. 1983, 11, 6723-6732.

70. LaMonte, B.L.; Hughes, J.A. In vivo hydrolysis of S-adenosylmethionine induces the met regulon of Escherichia coli. Microbiology 2006, 152, 1451-1459.

71. Maxon, M.E.; Wigboldus, J.; Brot, N.; Weissbach, H. Structure-function studies on Escherichia coli MetR protein, a putative prokaryotic leucine zipper protein. PNAS 1990, 87, 7076-7079.

72. Davidson, B.E.; Girons, I.S. The Escherichia coli regulatory protein MetJ binds to a tandemly repeated 8bp palindrome. Mol. Microbiol. 1989, 3, 1639-1648.

73. Urbanowski, M.L.; Stauffer, L.T.; Plamann, L.S.; Stauffer, G.V. A new methionine locus, metR, that encodes a trans-acting protein required for activation of metE and metH in Escherichia coli and Salmonella typhimurium. J. Bacteriol. 1987, 169, 1391-1397. 
74. Shoeman, R.; Redfield, B.; Coleman, T.; Brot, N.; Weissbach, H.; Greene, R.C.; Smith, A.A.; Saint-Girons, I.; Zakin, M.M.; Cohen, G.N. Regulation of the methionine regulon in Escherichia coli. BioEssays 1985, 3, 210-213.

75. Cai, X.; Jakubowski, H.; Redfield, B.; Zaleski, B.; Brot, N.; Weissbach, H. Role of the metF and metJ genes on the vitamin B12 regulation of methionine gene expression: involvement of N5-methyltetrahydrofolic acid. Biochem. Biophys. Res. Commun. 1992, 182, 651-658.

76. Hunter, J.S.; Greene, R.C.; Su, C.H. Genetic characterization of the metK locus in Escherichia coli K-12. J. Bacteriol. 1975, 122, 1144-1152.

77. Maxon, M.E.; Redfield, B.; Cai, X.Y.; Shoeman, R.; Fujita, K.; Fisher, W.; Stauffer, G.; Weissbach, H.; Brot, N. Regulation of methionine synthesis in Escherichia coli: effect of the MetR protein on the expression of the metE and metR genes. PNAS 1989, 86, 85-89.

78. Cai, X.Y.; Maxon, M.E.; Redfield, B.; Glass, R.; Brot, N.; Weissbach, H. Methionine synthesis in Escherichia coli: effect of the MetR protein on metE and metH expression. PNAS 1989, 86, 4407-4411.

79. Biran, D.; Gur, E.; Gollan, L.; Ron, E.Z. Control of methionine biosynthesis in Escherichia coli by proteolysis. Mol. Microbiol. 2000, 37, 1436-1443.

80. Born, T.L.; Blanchard, J.S. Enzyme-catalyzed acylation of homoserine: Mechanistic characterization of the Escherichia coli metA-encoded homoserine transsuccinylase. Biochemistry 1999, 38, 14416-14423.

81. Ron, EZ.; Alajem, S.; Biran, D.; Grossman, N. Adaptation of Escherichia coli to elevated temperatures: the metA gene product is a heat shock protein. Antonie Van Leeuwenhoek 1990, 58, 169-174.

82. Mordukhova, E.A.; Lee, H.; Pan, J. Improved thermostability and acetic acid tolerance of Escherichia coli via directed evolution of homoserine O-succinyltransferase. Appl. Environ. Microbiol. 2008, 74, 7660-7668.

83. Biran, D.; Brot, N.; Weissbach, H.; Ron, E.Z. Heat shock-dependent transcriptional activation of the metA gene of Escherichia coli. J. Bacteriol. 1995, 177, 1374-1379.

84. Wu, W.F.; Urbanowski, M.L.; Stauffer, G.V. Role of the MetR regulatory system in vitamin B12-mediated repression of the Salmonella typhimurium metE gene. J. Bacteriol. 1992, 174, 4833-4837.

85. González, J.C.; Peariso, K.; Penner-Hahn, J.E.; Matthews, R.G. Cobalamin-independent methionine synthase from Escherichia coli: A zinc metalloenzyme. Biochemistry 1996, 35, 12228-12234.

86. Kadner, R.J. Regulation of methionine transport activity in Escherichia coli.. J. Bacteriol. 1975, 122, 110-119.

87. Merlin, C.; Gardiner, G.; Durand, S.; Masters, M. The Escherichia coli metD locus encodes an ABC transporter which includes Abc (MetN), YaeE (Metl), and YaeC (MetQ). J. Bacteriol. 2002, 184, 5513-5517.

88. Kadner, R.J. Transport and utilization of D-methionine and other methionine sources in Escherichia coli. J. Bacteriol. 1977, 129, 207-216.

89. Kadner, R.J.; Winkler, H.H. Energy coupling for methionine transport in Escherichia coli. J. Bacteriol. 1975, 123, 985-991. 
90. Gál, J.; Szvetnik, A.; Ro'bert Schnell, R.; Kálmán, M. The metD D-methionine transporter locus of Escherichia coli is an ABC transporter gene cluster. J. Bacteriol. 2002, 184, 4930-4932.

91. Kadner, R.J. Transport systems for L-methionine in Escherichia coli. J. Bacteriol. 1974, 117, 232-241.

92. de Lorenzo, V.; Timmis, K.N. Analysis and construction of stable phenotypes in gram-negative bacteria with Tn5- and Tn10-derived minitransposons. Meth. Enzymol. 1994, 235, 386-405.

93. McAdam, R.A.; Weisbrod, T.R.; Martin, J.; Scuderi, J.D.; Brown, A.M.; Cirillo, J.D.B.; Jacobs, J.W.R. In vivo growth characteristics of leucine and methionine auxotrophic mutants of Mycobacterium bovis BCG generated by transposon mutagenesis. Infect Immun. 1995, 63, 1004-1012.

94. Engel, P.; Wright, M.S. Auxotrophs produced by transposon mutagenesis in Streptomyces tendae ATCC 31160. Lett. Appl. Microbiol. 1991, 13, 51-54.

95. Kwon, Y.M.; Ricke, S.C. Efficient amplification of multiple transposon-flanking sequences. $J$. Microbiol. Meth. 2000, 41, 195-199.

96. Kwon, Y.M.; Kubena, L.F.; Nisbet, D.J.; Ricke, S.C. Functional screening of bacterial genome for virulence genes by transposon footprinting. Methods Enzymol. 2002, 358, 141-152.

97. Lee, S.; Jeon, B.; Bardarov, S.; Chen, M.; Morris, S.L.; Jacobs, W.R., Jr. Protection elicited by two glutamine auxotrophs of Mycobacterium tuberculosis and in vivo growth phenotypes of the four unique glutamine synthetase mutants in a murine model. Infect. Immun. 2006, 74, 6491-6495.

98. Bauby, H.; Saint Girons, I.; Picardeau, M. Construction and complementation of the first auxotrophic mutant in the spirochaete Leptospira meyeri. Microbiology 2003, 149, 689-693.

99. Li, X.; Ricke, S.C. Generation of an Escherichia coli lysA targeted deletion mutant by double cross-over recombination for potential use in a bacterial growth-based lysine assay. Lett. Appl. Microbiol. 2003, 37, 458-462.

100. Stragier, P.; Borne, F.; Richaud, F.; Richaud, C.; Patte, J.C. Regulatory pattern of the Escherichia coli lys $A$ gene: expression of chromosomal lysA-lacZ fusions. J. Bacteriol. 1983, 156, 11981203.

101. Greene, R.C.; Smith, A.A. Insertion mutagenesis of the metJBLF gene cluster of Escherichia coli K-12: evidence for an metBL operon. J. Bacteriol. 1984, 159, 767-769.

102. Blanco, J.; Coque, J.J.R.; Martin, J.F. The folate branch of the methionine biosynthesis pathway in Streptomyces lividans: Disruption of the 5,10-methylenetetrahydrofolate reductase gene leads to methionine auxotrophy. J. Bacteriol. 1998, 180, 1586-1591.

103. Kuhn, J.; Somerville, R.L. Mutant strains of Escherichia coli K12 that use D-amino acids. PNAS 1966, 68, 2484-2487.

104. Cooper, A.J.L. Biochemistry of sulfur-containing amino acids. Annu. Rev. Biochem. 1983, 52, 187-222.

105. Cooper, S. Utilization of D-methionine by Escherichia coli. J. Bacteriol. 1966, 92, 328-332.

106. Kadaba, N.S.; Kaiser, J.T.; Johnson, E.; Lee, A.; Rees, D.C. The high-affinity E. coli methionine ABC transporter: Structure and allosteric regulation. Science 2008, 321, 250-253. 
107. Ripp, S.A.; Sayler, G.S. In Environmental assessment: bioreporter systems. In Molecular Microbial Ecology; Osborn, A.M., Smith, C.S., Eds.; Taylor \& Francis Group: New York, NY, USA, 2005; p. 321.

108. Tuffnell, J.M.; Payne, J.W. A colorimetric enzyme assay using Escherichia coli to determine nutritionally available lysine in biological materials. J. Appl. Bact. 1985, 58, 333-341.

109. Griffiths, M.W. Bioluminescence and the food industry. J. Rapid Meth. Auto. Microbiol. 1995, 4, 65-75.

110. Lakowicz, J.R. Principles of Fluorescence Spectroscopy; Kluwer Academic/Plenum Publishers: New York, NY, USA, 1999.

111. Kavanagh, F. Analytical Microbiology; Academic Press: New York, NY, USA, 1963.

112. Erickson, A.M.; Zabala-Díaz, I.B.; Ricke, S.C. Antibiotic amendment for suppression of indigenous microflora in feed sources for an Escherichia coli auxotroph lysine assay. J. Appl. Microbiol. 1999, 87, 125-130.

113. Froelich, C.A.; Zabala-Díaz, I.B.; Ricke, S.C. Methionine auxotroph Escherichia coli growth assay kinetics in antibiotic and antifungal amended selective media. J. Environ. Sci. Health. 2002, B37, 485-492.

114. Miller, J.H. In Experiments in Molecular Genetics; Cold Spring Harbor Laboratory Press: New York, NY, USA, 1972.

115. Lin, E.C.C. Dissimilatory pathways for sugars, polyols, and carboxylates. In Escherichia coli and Salmonella: Cellular and Molecular Biology; Neidhardt, F.C., Curtiss III, R., Ingraham, J.L., Lin, E.C.C., Low, K.B., Magasanik, B., Reznikoff, W.S., Riley, M., Schaechter, M., Umbarger, H.E., Eds.; ASM Press: Washington, DC, USA, 1996; Volume 1, p. 307.

116. Baldwin, T.O.; Devine, J.H.; Heckel, R.C.; Lin, J.W.; Shadel, G.S. The complete nucleotide sequence of the lux regulon of Vibrio fischeri and the luxABN region of Photobacterium legiognathi and the mechanism of control of bacterial bioluminescence. J. Biolumin. Chemilum. 1989, 4, 326-341.

117. Rodriguez, J.F.; Rodriguez, D.; Rodriguez, J.R.; McGowan, E.B.; Esteban, M. Expression of the firefly luciferase gene in vaccinia virus: a highly sensitive gene marker to follow virus dissemination in tissues of infected animals. PNAS 1988, 85, 1667-1671.

118. Baker, J.M.; Griffiths, M.W.; Collins-Thompson, D.L. Bacterial bioluminescence: application in food microbiology. J. Food Prot. 1992, 55, 62-70.

119. Hill, P.J.; Stewart, G.S.A.B. Use of $l u x$ genes in applied biochemistry. J. Biolumin. Chemilumin. 1994, 9, 211-215.

120. Froelich, C.A.; Zabala-Díaz, I.B.; Ricke, S.C. Construction and growth kinetics of a bioluminescent methionine auxotroph Escherichia coli strain for potential use in a methionine bioassay. J. Rapid Methods Auto. Micro. 2002, 10, 69-82.

121. Robinson, K.R.; Keating, T.J.; Cork, R.J. Intensive techniques for measuring $\left[\mathrm{Ca}^{2+}\right]_{\mathrm{i}}$ changes using a photomultiplier tube. Meth. Cell Biol. 1994, 40, 287-303.

122. Tsien, R.Y. The green fluorescent protein. Annu. Rev. Biochem. 1998, 67, 509-544.

123. Valdivia, R.H.; Falkow, S. Bacterial genetics by flow cytometry: rapid isolation of Salmonella typhimurium acid-inducible promoters by differential fluorescence induction. Mol. Microbiol. 1996, 22, 367-378. 
124. Hack, N.J.; BiHups, B.; Gutherie, P.B.; Rogers, J.H.; Muir, E.M.; Parks, T.N.; Kater, S.B. Green Fluorescent protein as a quantitative tool. J. Neuroscience Meth. 2000, 95, 177-184.

125. Shimomura, O.; Johnson, F.H.; Saiga, Y. Extraction, purification and properties of aequorin, a bioluminescent protein from the Luminous Hydromedusan, Aequorea. J. Cell. Comp. Physiol. 1962, 59, 223-239.

126. Burlage, R.S. Emerging technologies: bioreporters, biosensors, and microprobes. In Manual of Environmental Microbiology; Hurst, C.J., Knudsen, G.R., McInerny, M.J., Stetzenbach, L.D., Walter, M.V., Eds.; ASM Press: Washington, DC, 1997; p. 115.

127. Froelich, J.C.A.; Zabala Díaz, I.B.; Chalova, V.I.; Kim, W.; Ricke, S.C. Quantifying methionine with a green fluorescent Escherichia coli methionine auxotroph. J. Rapid Meth. Auto. Microbiol 2005, 13, 193-203.

128. Billinton, N.; Knight, A.W. Seeing the wood through the trees: a review of techniques for distinguishing green fluorescent protein from endogenous autofluorescence. Anal. Biochem. 2001, 291, 175-197.

129. Heim, R.; Tsien, R.Y. Engineering green fluorescent protein for improved brightness, longer wavelengths, and fluorescence resonance transfer. Current Biol. 1996, 6, 178-182.

130. Crameri, A.; Whitehorn, E.A.; Tate, E.; Stemmer, W.P.C. Improved green fluorescent protein by molecular evolution using DNA shuffling. Nature Biotech. 1996, 14, 315-319.

131. Patterson, G.H.; Knobel, S.M.; Sharif, W.D.; Kain, S.R.; Piston, D.W. Use of the green fluorescent protein and its mutants in quantitative fluorescence microscopy. Biophys. J. 1997, 73, 2782-2790.

132. Chalova, V.; Woodward, C.L.; Ricke, S.C. Application of an Escherichia coli green fluorescent protein-based biosensor under nonsterile conditions and autofluorescence background. Lett. Appl. Microbiol. 2006, 42, 265-270.

133. Andersen, J.B.; Sternberg, C.; Poulsen, L.K.; Bjørn, S.P.; Givskov, M.; Molin, S. New unstable variants of green fluorescent protein for studies of transient gene expression in bacteria. Appl. Environ. Microbiol. 1998, 64, 2240-2246.

(C) 2010 by the authors; licensee Molecular Diversity Preservation International, Basel, Switzerland. This article is an open-access article distributed under the terms and conditions of the Creative Commons Attribution license (http://creativecommons.org/licenses/by/3.0/). 